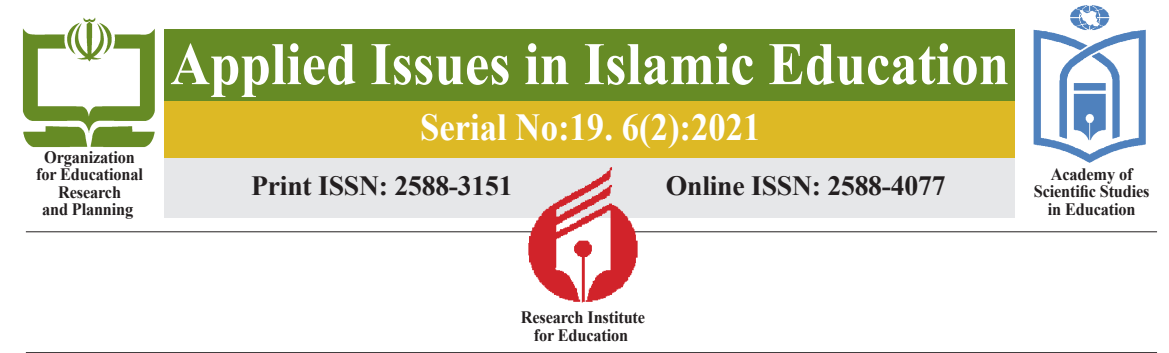

\title{
The Explanation of Spiritual Education for Children (S4C) with an Emphasis on the Theoretical Foundations of Fundamental Transformation in the Formal Public Education System of Iran and Examining E-learning Opportunities and Challenges for it
}

\footnotetext{
- Masoume Kiyani ${ }^{1}$ = Maryam Pour-Jamshidi ${ }^{2}$

- Objective: The purpose of this study is to explain the concept of spiritual education for children(S4C) and its principles with an emphasis on the Theoretical Foundations of Fundamental Transformation in the Formal Public Education System of Iran, and exploring the opportunities and challenges of e-learning for it.
}

- Research Method: This is a qualitative research, and its statistical population consists of the document of Theoretical Foundations of Fundamental Transformation and all available texts and resources related to the concept of spirituality and spiritual education for children as well as e-learning. The statistical sample was selected through purposive means. Then, using the method of transcendental analysis, the concept of children's spiritual education according to the Theoretical Foundations of Fundamental Transformation was explained, and using Frankena's deductive model, three important principles of children's spiritual education related to its cognitive aspect were inferred and explained, and then, using descriptive-analytical method, the opportunities and challenges of e-learning in achieving the mentioned principles were discussed.

- Results: The results of the analysis showed that the spiritual education for children(S4C) focuses on the knowledge about Allah as the source of spirituality, nurturing the child's spirit and inclinations towards Allah, and the realization of a 'Purified life' in all aspects of the child's life. It was also clarified that the three important principles of children's spiritual education in its cognitive aspect are: the principle of cultivating correct thoughts and beliefs about Allah as the source of spirituality; developing the child's perspective on the beliefs and spiritual possibilities of his/ her religion and other traditions and religions; fostering the children's critical thinking. Furthermore, developing children's spiritual literacy through open sources, access to reference human resources with the least restrictions, and creating spiritual communities are some of the opportunities of e-learning for S4C. Also, empowerment of teachers and management of children's educational process, their need to have the necessary attitudes and communication skills in e-learning, the monitoring and guiding learners' participation, and understanding distance learning from children's viewpoint, and evaluating and guiding children towards self-direction are some of the major challenges of e-learning for S4C.

- Conclusion: Children should acquire the necessary spiritual literacy in the field of spiritual education based on the Theoretical Foundations of Fundamental Transformation so that they can act wisely and consciously about their spiritual orientation. In this regard, e-learning opportunities can be used to overcome its limitations and challenges for the spiritual education of children.

\section{Keywords: spiritual education, children, educational principles, e-learning}

Citation: Masooma Kiani, Maryam Pour-Jamshidi.(2021). The Explanation of Spiritual Education for Children(S4C) with an Emphasis on the Theoretical Foundations of Fundamental Transformation in the Formal Public Education System of Iran and Examining E-learning Opportunities and Challenges for it, Applied Issues in Islamic education, 6(2):109-132.

Received: $2021 / 05 / 18$

Accepted: 2021/07/01

1. Corresponding Author: An Assistant Professor of Philosophy of Education, Faculty of Humanities, Department of Educational Sciences, Bu Ali Sina University, Hamadan, Iran.

Email: m.kiyani@basu.ac.irm. (iD) 0000-0002-9134-2457

2. Assistant Professor of Educational Technology, Faculty of Humanities, Department of Educational Sciences, Bu Ali Sian University, Hamadan, Iran.

Email: m.pourjamshidi@basu.ac.irm. (iD) 0000-0002-2296-1836 



\section{تببيين تربيبت معنوى براى كودكان

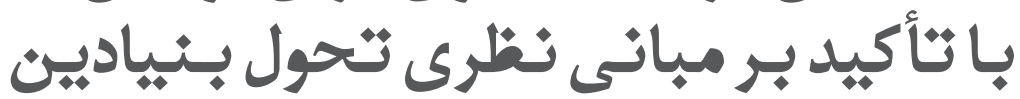 \\ در نظام تربيبت رسمى بعمومى اييران

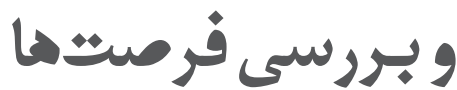 \\ و خالشهاى يادَّيرى الكترونيكى براى آن}


همجنين، توسعه سواد معنوى كودكان از طريق منابع باز، دسترسى به منابع انسانى مرجع

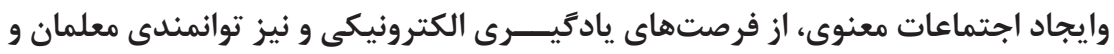

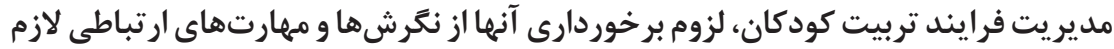

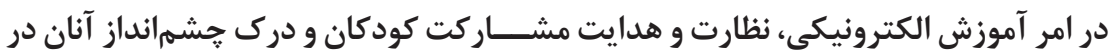

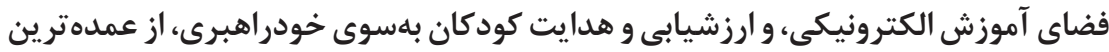

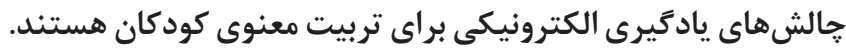
ه نتيجهَيرى: كودكان بايد در عرصه تربيت معنوى، ســــواد معنوى لازم را كسب تا بتوانند

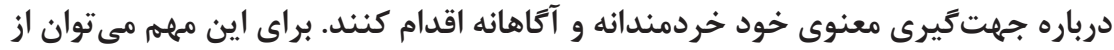

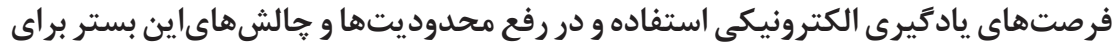
تربيت معنوى كودكان اقدام نمود.

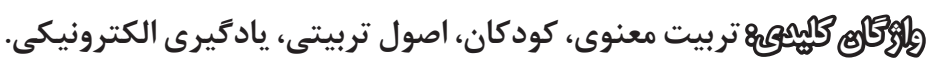

\section{مثندمه}

امروزه كودكان و جوانان ما با مســائل و اتفاقاتى در جامعه و جهان روبهرو مىشوند كه انسان را به تفكر درباره معنا، ارزش و حقيقت غايى زندگى سوق مى دهد و نمىتوان

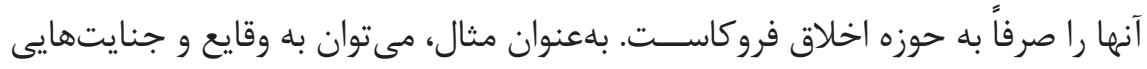
مانند كودك كشىها، شكنجهها و كثــتن انسانهاى بى گَناه و غيره كه از سوى داعش و با ادعاى ديانت صورت مى گيرد اشــاره كرد. همجنـين شــــاهدى نظير جنايت انسانى درباره هيروشيما، هلو كاست و كورههاى ادم سوزى، جنگهاى جهانى اول و دوم و برخى آشفتخى ها در جوامع مختلف، از ناتوانى عقل بشر و اومانيسم در نيل انسان به آرامش و رستخارى، و وجود خلأ معنوى در قلب عصر مدرن حكايت دارد. جنين مسائلى انسانها

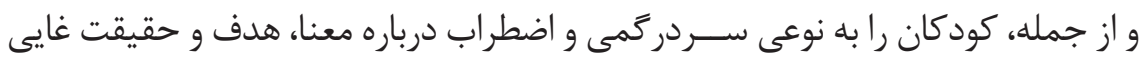
زندكَـى دجار كرده اســت (13-13) :Wright, 2000). علاوه برايــن، امروز بازار فكرى و

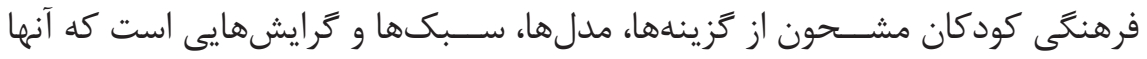
را به ســمت تعريف و قرائت خود از معنا، ارزش، و حقيقت غايى زندگى ســـــ مى مهدد مانند عرفان حلقه، اكنكار، شــيطان يرستى، ايليا رامالله و ساير عرفانهاى نوظهور دينى و غيردينى. اين درحالى اســت كه انقلاب ارتباطات و جهانى شــدن، فضاهاى مجازى و وســعت نشـــر اطلاعات نادرست و مبهرم از يكى ســـو، و غفلت مدارس از توجه به تربيت 
معنوى كود كان و توانمندسـازى آنان براى مواجهه آكاهانه و خردمندانه با جهت گيرى معنوى خود از سوى ديخر، كود كان را بيش از هر زمان ديخرى در وضعيتى بحرانى قرار داده است. از اينرو، ضرورى است كه نهاد تعليم و تربيت، يرورش كليت كودى را مورد توجـــه قرار دهد و به كودكان كمك كند تادربــاره جهـت گيرى معنوى خود با درايت و حسايت بيشترى عمل كنند. بر همين اساس، تربيت معنوى كودكان دركانون تحقيقات مختلف|نديشمندان تعليم و تربيت قرار گرفته است. درباره مفهوم تربيت معنوى براى كودكان ديدگاههاى مختلفى وجود دارد؛ بهعنوان

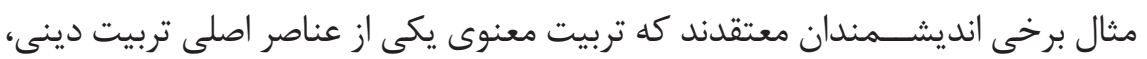

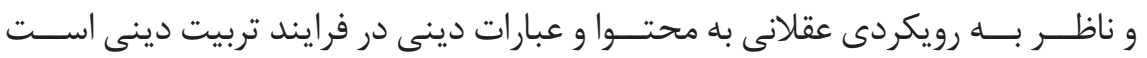
(Gellel, 2014: 65). همجنين برخى نويسند معنوى را شكل رسمى تربيت معنوى معرفى مى كنند (Watson, 2009: 824). به اعتقاد برخى ديگًر رويكرد معنوى به تربيت، بسيارى از اصول و ارزشهاى تربيت ييشرفت دربرمى گيرد. Ramsey (Watson, De Souza \& Trousdale, 2014: 298) نيز برعنصر تجربه زيســته و ارتباطات كودكان و درك انسانيت در امر تربيت معنوى كودكان تأكيد مى كند (Ramsey, 2014: 119-122). بـــا توجه به ديدكاههاى فوق مى توان اظهار نمود كــــهـ تربيت معنوى براى كودكان،

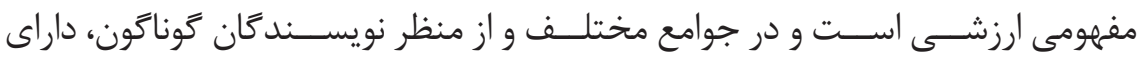
;Moberg, 2010 مبانى فلســـى مختلف و تعاريف متفاوتى است (ر.ج. تحقيقاتى مانند

(Wright, 2000: 7-14; Crawford \& Rossiter, 2006 همجنين، يرورش بعد معنوى متربيان ارتباط تنگَاتنگى با ســلامت و سعادت اقشار مختلف جامعه و از جمله كود كان دارد. بنابراين با توجه به اينكه هر جامعهاى متناسب با مبانى فلسفى، دينى و فرهنگى خود به تعريف تربيت معنوى كودكان اقدام مى كند ارائه تعريفى از مفهوم تربيت معنوى براى كودكان با ابتناء بر مبانى فلســفى تعليمى و تربيت جمهورى اســلامى ايران امرى ضرورى است. براى اين امر، مبانى نظرى تحول بنيادين باعنوان يايگاه نظرى تحقيق حاضر در نظر گرفته شد. از سوى ديخر دنياى كنونى ما مملو از فناورىهاى ديجيتالى است كه به ضرورت يك زندگى 
موفق تبديل شدهاند؛ باويزه براى كودكان امروز كه بوميان عصر ديجيتال محسوب مىشوند. در اين شرايط، محيطهاى آموزشــى كودكان نيز به واسطه تغيير و تحولات عصر ارتباطات و فناورىهاى ديجيتال دســتخوش تغييرات مهرى شده و يادگيرى الكترونيكى ييامد اين

تغييرات است (Gerasimova, Melamud, Tutaeva, Romanova \& Zhenova, 2018). يادَيرى الكترونيكى، محيط يادگيرى اســت كــهـ در آن تعامل يادَّيرنده با محتوا، ســاير يادگيرند گان و با معلمان بهواســـه فناورى اطلاعات و ارتباطات انجام مى گيرد. (Negahban \& Selvaraja, 2019) ديجيتال قرار دارد، بخشــى لاينفك از يادگيرىهاى كودكان امروز است. اخرجه فرايند جهانى شــدن و انقلاب ارتباطات با عرضه انبوه منابع متنوع و گَاه متعارض هويتســاز موجب بحران هويت در ميان بســيارى از اقشار جامعه(خواجه نورى و يرنيان، Fوس ( ) و از جمله كودكان شده است و تحقيقات مختلف از ييامدهاى منفى فضاى مجازى نظير؛ ترويج و عادى سازى خانوادههاى لجام گسيخته در مقابل ساختار خانواده، عادى سازى روابط غيراخلاقى و نامشروع، ترويج فرهنَ همباشى به جاى ازدواج، و انزواى اجتماع بر معناســازى كود كان و شكل گيرى هويتايشان حكايت دارد(شكوهى و اصغرزاده طالبى، צ૧سا)، در مقابل، بستر يادگيرى الكترونيكى بهواسطه برخوردارى از قابليتهاى متنوع، به طراحان و برنامهريزاناين امكان را مىدهد تا براى مخاطبان مختلف و طيفهاى سنى متفـــاوت، آموزشهاى با كيفيتترى را تدارك ببينـند (نوراللمهى، حكيهم زاده، ســـراجى، نظرزاده زارع، جوس|). براين اســاس مىتــوان اظهار نمود كهاين فناورى مىتواند فضا و شـــايطى رادر اختيار معلمان و دســاندر كاران تعليم و تربيت قرار دهد تا كودكان را جهت تشــخيص، ارزيابى، و اتخاذ جهت گيرى معنـــوى خردمندانه و آكاهانه و انتقادى

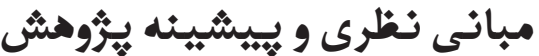

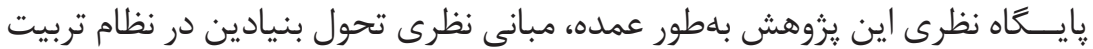
رسمىعمومى جمهورى اســلامى ايران است. اين سند ضمن تشـــريح و توضيح مبانى فلســفى، دينى و فرهنگى نظام تعليم و تربيت رســمى عمومى جمههورى اسلامىايران، بهعنوان مبنايى براى تمامى سياستخذارىها، برنامهريزىها، و برنامههاى راهبردى نظام 
تعليم و تربيت ايران محسوب مىشود. در عين حال، اين يزوهش به موازات بحث، از مبانى

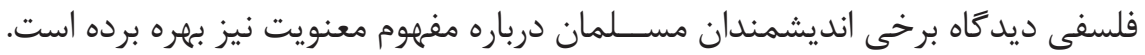

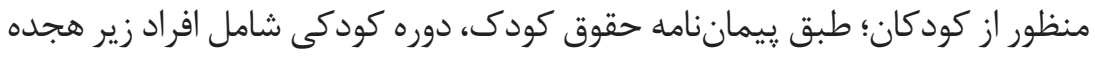

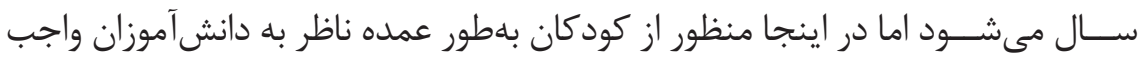
التعليم و منظور از تربيت، تربيت رسمى است است.

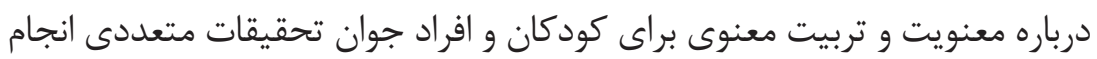

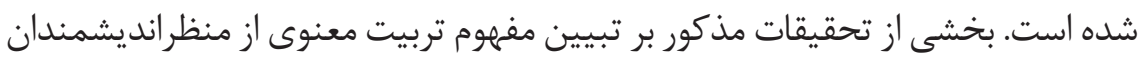

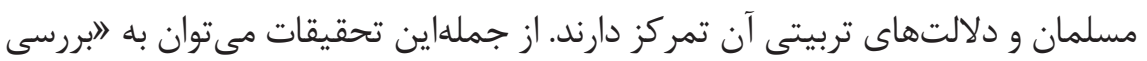

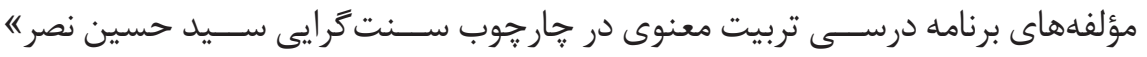

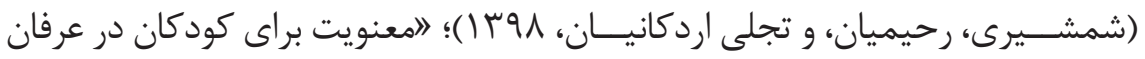

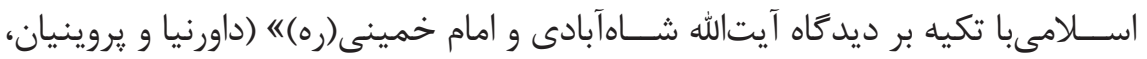

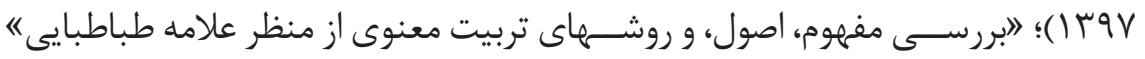

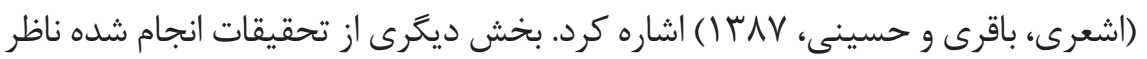

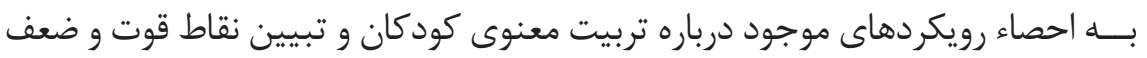

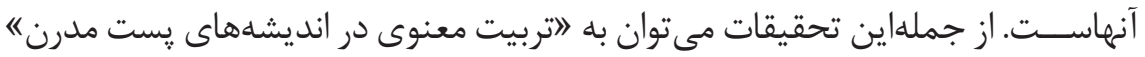

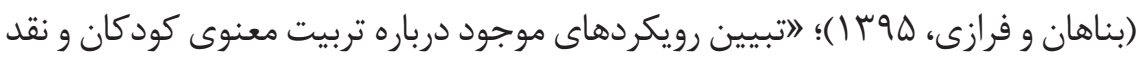

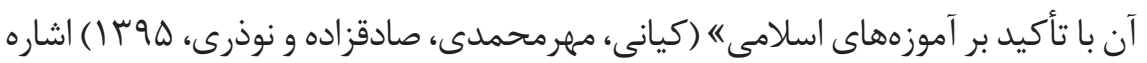

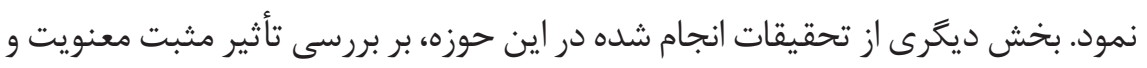

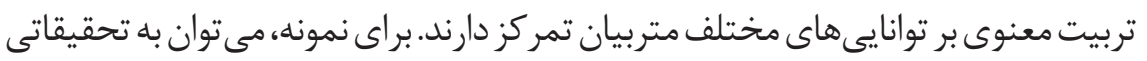

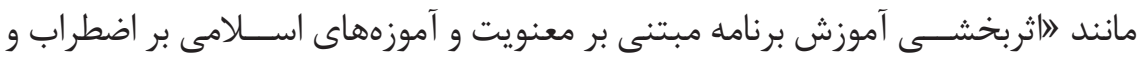

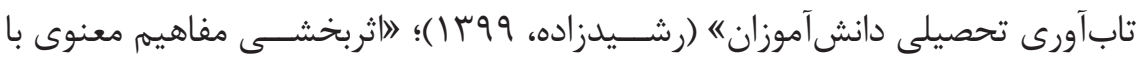

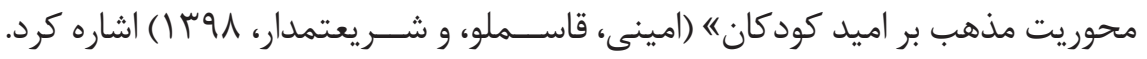

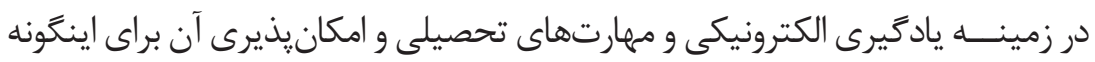

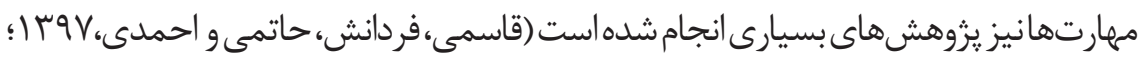

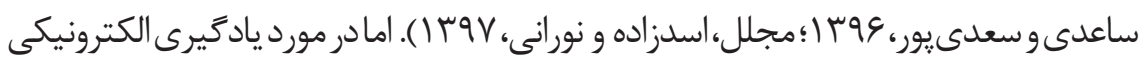

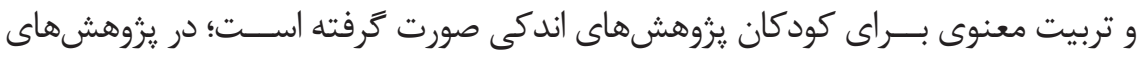


به ضرورت يرداختن به يرورش بعد معنوى يادَيرندگان در فضاهاى مجازى اشاره شده اســت نيز نتايج برخى از يروهشها مانند مطالعه (Hasanshahi, \& Mazaheri, 2016) نشــاندهندهى تأثير شــبكههاى اجتماعى مجازى بر بهبود معنويت دانشجويان است. در مجمـــوع، يزوهش در زمينه تربيت معنوى و فضاهــاى الكترونيكى براى يرورش آن

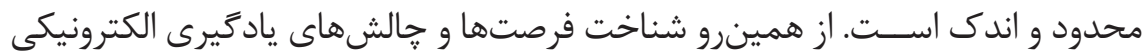
براى تربيـت معنوى كودكان در دنياى امروز كه فناورىهــاى الكترونيكى در عرصهى آموزش و يرورش نفوذ جشمخيرى ييدا كردند و موجب تغيير شكل آموزش و يادكيرى بهصورت الكترونيكى شـــند، امرى ضرورى است و مى تواند در برنامهريزى جهت ايجاد بستر مناســب به منظور دستيابى به اهداف نظامهاى آموزشـى بهويزه در بعد تربيت معنوى كود كان مؤثر باشد.

\section{روشتحثيق}

روشايــن يزوهش كيفى، و جامعه تحليلى آن؛ ســند مبانى نظرى تحول بنيادين، و منابــع موجود ييرامون مفهوم معنويــت و تربيت معنوى براى كودكان و نيز يادكيرى الكترونيك اســت كه با توجه به هدف هر ســـؤال يزوهشى،اين منابع بهصورت هدفمند

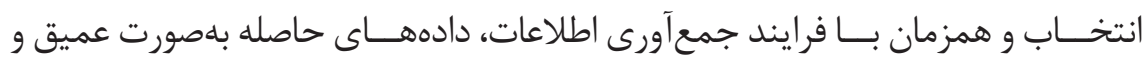
مســـتمر مطالعه و مورد تجزيه و تحليل قــرار گرفتند. روش هاى مورد اســتفاده براى يُاســخَّويى به سؤالات يزوهش حاضر عبارتند از: روش توصيفى - تحليلى، روش تحليل

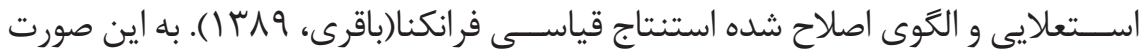
كه، در راستاى تبيين مفهوم تربيت معنوى براى كودكان با تأكيد بر مبانى نظرى تحول بنيادين، ابتدا با استفاده از روش توصيفى -تحليلى، مفهوم معنويت از ديدگاهانديشمندان مســلمان، توصيف و منظور از آن در مبانى نظرى تحول بنيادين تصريح گرديد. سيس مبانى هستى شناسـىى، معرفتشناسى و ارزش شناسى ناظر بر ساختار مفهوم معنويت از ســند مبانى نظرى تحول بنيادين، شناسايى و در مرحله بعد، با تكيه بر مبانى بهدست آمده، مفهوم تربيت معنوى براى كودكان استباط شد(روش تحليل استعلايى). در ادامه، با اســـفاده از الخوى استتنتاج قياسى فرانكنا، سه اصل مهلم از اصول تربيت معنوى براى كود كان در وجه شناختى استنباط گرديد. براى استنتاج يك اصل از هدف تربيتى، گزاره 
واقعنكر به كزاره مربوط به هدف افزوده شـــد. بدينترتيب، با استفاده از روش قياسى، از

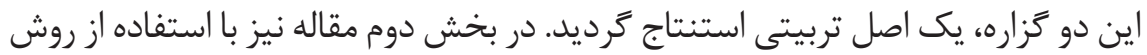

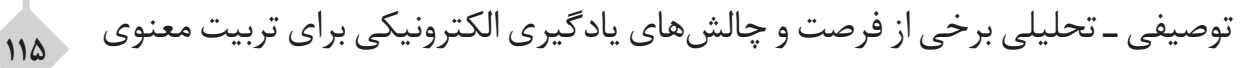

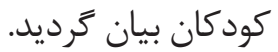

\section{بافنهافا}

يافتههاى يزوهش بر دو محور اصلى اســتوار اســت. محور نخست، به تبيين مفهوم

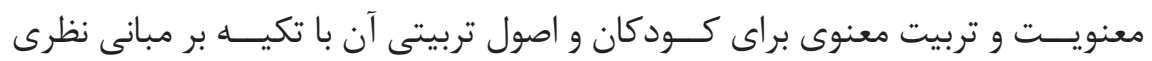

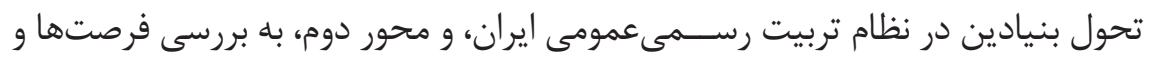

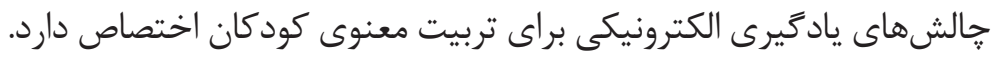

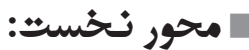

\section{تبييبن مغهوم معنويت از منظر انديشمندان مسلمان و مبانى نظرى تحول بـنيادين}

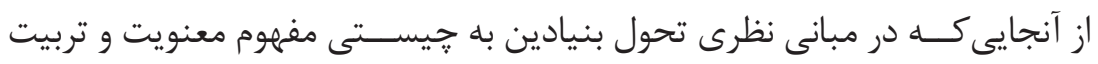

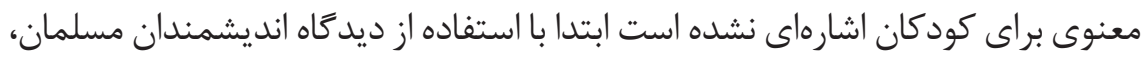

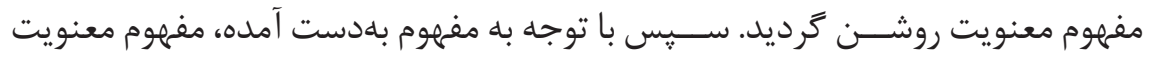

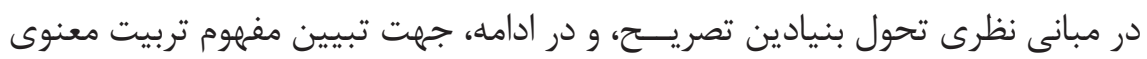

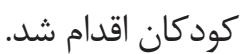

شهيد مطهرى در بررسى مفهوم آزادى معنوى و تمايز آن از آزادى اجتماعى، با تكيه

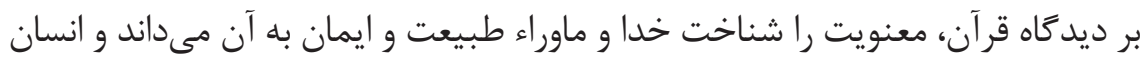

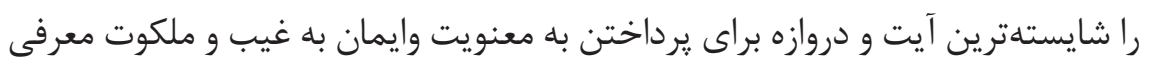

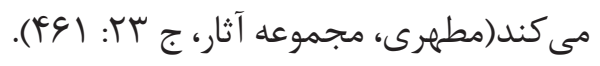

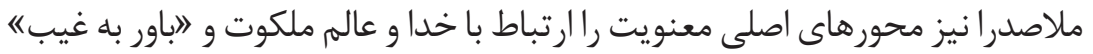

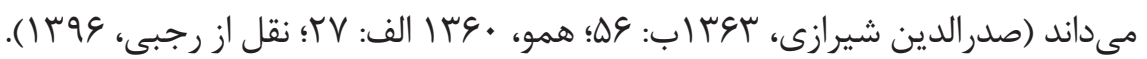

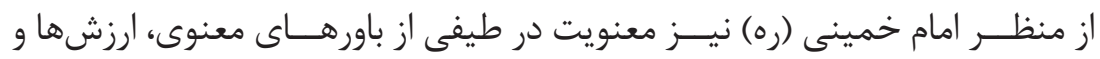

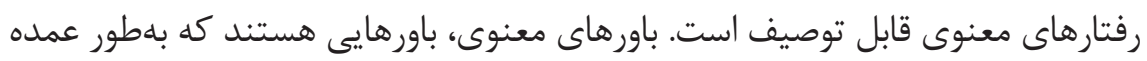

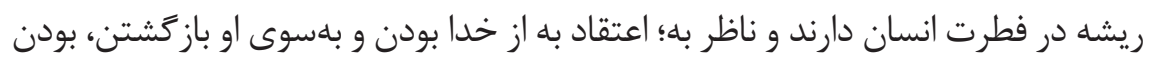

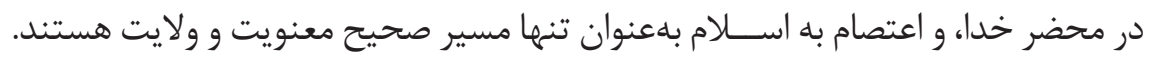


ارزشهاى معنوى نيز همان ارزش هاى اســلامىمانند؛ايمان به خدا، اخلاص، جهاد اكبر، تقوا، شـــاعت، اســـقامت،ايثار و دفاع از اسلام اســـت. رفتارهاى معنوى نيز عبارتند از رفتارهايى نظير؛ عمل به تكاليف شرعى همجون عبادات، جلب رضاى خدا با خدمت به همنوعان، رعايت حقوق ديخران، كه افراد معنوى معمولاً در قبال خداوند، خود، ديخران و طبيعت انجام مى دهند (الوندى، سوس ). نيــز اظهار مـــــــ (Bagheri Noparast, 2013) اســت كه بهمعناى مادى محدود به زمان و مكان، فروكاسته نمىشود؛ امر معنوى، اينجا

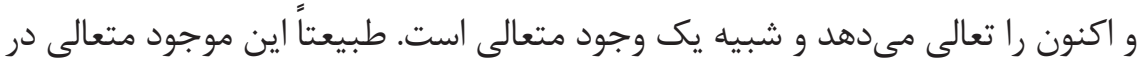
اسلام، خداوند است. يس، يك معناى متعالى مرتبط با خدا در معنويت مورد نظر است. طبق مبانى نظرى تحول بنيادين نيز غايت، نتيجه و هدف كلى تربيت عبارت است از: تحقق آتاهانه و اختيارى مراتب حيات طيبه در همه ابعاد و با تكيه بر نظام معيار دينى

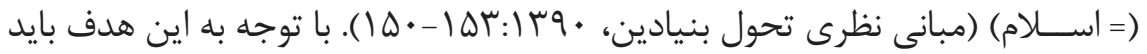
تعريف مفهوم تربيت معنوى براى كودكان و بالتبع، مفهوم معنويت را در حدود و قلمرو دين اسلام جستجو نمود. همان طور كه يافتههاى تحقيقات مختلف نشان مى دهد معنويت از منظر اسلام ناظر بهمعنايى در ارتباط با خداى تعالى، باور به غيب و عالم باطن، باور به رشــد و بالندگى انسان بر مبناى تنظيم زندگى حول ارتباط با آن وجود متعالى و درى

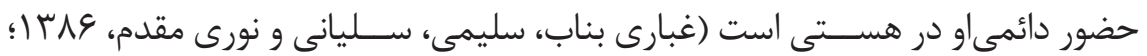

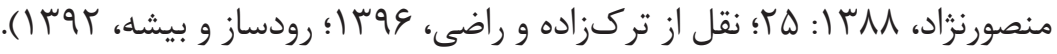
بنابراين مى توان اظهار نمود معنويت از منظر انديشــمندان مسلمان عبارت است از شناخت خداوند و قرب به او. اين مفهوم در سند تحول بنيادين ناظر به مفهوم "اقرب الىالله است. قرب الى الله عبارت است از: لرابطهاى حقيقى بين خدا و انسان؛ به گونهاى كه روح انسان در اثر درك، باور و اعمالى خاص، رابطهاى وجودى و آزادانه با خداى متعال برقرار و بهطور مداوم آن را تشــديد مى كنـــد و در نتيجهى ايجاد جنـين ارتباطى مراتب كمال

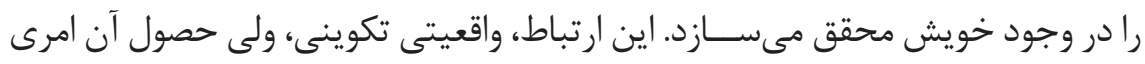
اكتسابى و اختيارى است. البتهاين ارتباط وجودى با خداوند امرى داراى مراتب و درجات است كه مىتواند بهطور مداوم تشــديد شود يا تنزل يابده، نيل آدميان به قرب الى الله، مستلزم تحقق اختيارى نوعى زندگى شايسته انسان بر اساس نظام معيار دينى است كه 


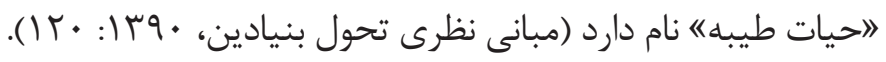
مفهـــوم لاقرب الى الله/ مفهومى بزركتر از دين اســت زيرا هم در بســتر دين و هم خارج از بســتر ديسـن موضوعيت دارد. مفهوم قرب الى الله، جنـــد وجهـى و داراى مراتب مختلف است. از اينرو، صرفاً مختص دينداران نيست و مىتواند مراتبى داشته باشد كه

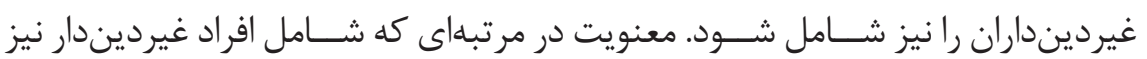
مىشود ناظر به معانى و ارزشهايى است كه فرد در ارتباط با خود و مواجهه با اجتماع، فرهنَ و محيط ييرامون شناسـايى مى كند و مىسازد. اين سطح از معنويت را مىتوان

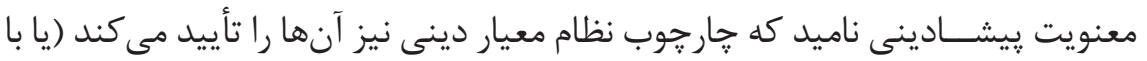

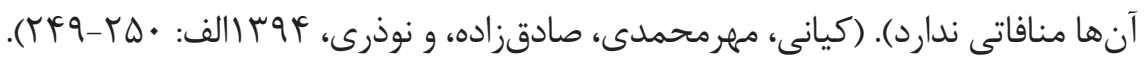

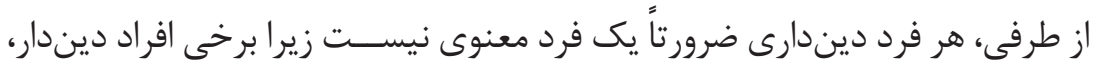
ظاهر گرا هســـتند و از ســــح احكام و ظاهر دين فراتر نمىروند. معنويت در اين سطح،

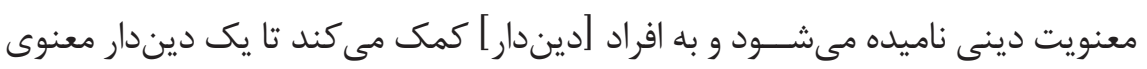
باشند. در عين حال، سطح ديخرى از معنويت وجود دارد كه ناظر به جستجو و شناخت معنى، ارزش و حقيقت غايى زندگى است. اين امور فارغ از بستر يك دين خاص مطرح

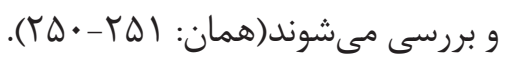

\section{م مفهوم تربيت معنوى براى كودكان با تأكيد بـر مبانى نظرى تحول بـنيادين در نظام}

\section{تربيت رسمى عمومى}

بـــه منظور تبيين مفهوم تربيت معنوى براى كود كان، با تكيه بر روش فرارونده، ابتدا طبق ساختار مفهوم معنويت در سند مبانى نظرى تحول بنيادين، مبانى هستىشناسى، معرفتشناسى و ارزششناسىاين مفهوم تصريح و سيس مفهوم مذكور استنباط گرديد.

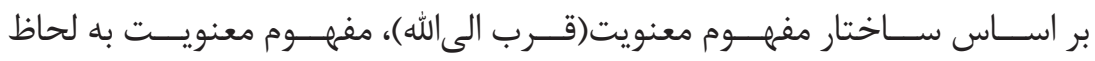
هستى شناختى با يك امر قدسى در ارتباط است. بنابراين در ميان مبانى هستىشناختي مئي مبانى نظرى تحول بنيادين، بايد به آن مواردى از مبانى هستىشناســى رجوع كرد كه

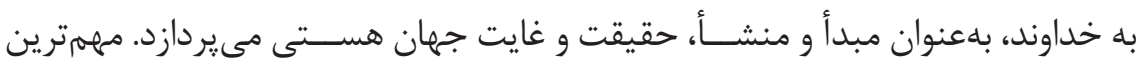
اين مبانى عبارتند از: خداوند مبدأ و منشأ جهان و يعانه مالك، مدبر و رب حقيقى همه موجودات عالم است؛ آفرينش جهان هستى غايتمند و خداوند غايت همه موجودات است 
نيز ساختار مفهوم معنويت به لحاظ انسانشناختى ناظر به بعد روحانى انسان و وجود فطرت در اوســت. برخى از مهمهتريناين مبانى در اينجا عبارتند از: تشكيل وجود انسان از دو بعد جســم و روح؛ اصالت روح بهعنوان حقيقت وجود انسان؛ برخوردارى انسان از فطرت الهى؛ برخـــوردارى از آزادى و قدرت اختيار(مبانى نظرى تحول بنيادين، • وبا: .$(\Delta \vee-\varphi \Delta, \vee q-V \wedge$ طبق ســاختار مفهوم معنويت، به لحاظ معرفتشـــاختى نيز بايد به آن مواردى از مبانى معرفتشناســى مبانى نظرى تحــــل بنيادين رجوع كرد كه ناظر به صحت تصور ما درباره وجود خداوند و شـــاخت اوست. در واقع مواضع معرفتشناختى مختلف داراى مدي معيارهاى مختلفى براى شناخت صحيح مرجع امر معنوى است. مهمترين مبانى مذكور در سند مبانى نظرى تحول بنيادين عبارتند از: اكتشافى بودن علم، مطابقت علم با واقع،

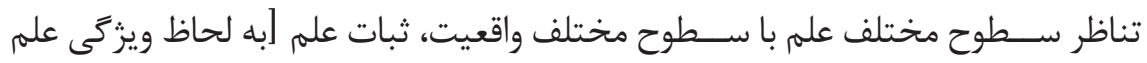

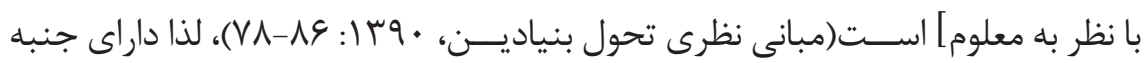
رئاليستى است. براين اساس، يك خداى واقعى وجود دارد كه داراى صفاتى واقعى و قابل شناخت است. با اينحال ممكن است شناخت فرد از خداوند، ناقص يا ناصحيح باشد كه با استفاده از اين مبنا قادر به تعالىاين شناخت يا اصلاح آن مىشود. نيز با توجه به اين نكته كه مفهوم معنويت، ناظر به مفهوم قرب الىالله است و آن نيز با مفهوم حيات طيبه دو روى يك سكه را تشكيل مىدهند (Bagheri Noparast, 2013) مى توان اظهار نمود كه به لحاظ ارزششناختى ناظر به مبناى لاتحقق حيات طيبه در همه ابعاد و شئون" مىباشد؛ حيات طيبه وضع مطلوب زندگى بشر بر اساس نظام معيار ربوبى اســت كه با انتخاب و التزام آكاهانه و اختيارىاين نظام معيار در همين زندگى دنى دنيايى و در جهت تعالى آن، از سوى خداوند به انسان اعطا مىشود و تحقق آن باعث دستيابى به

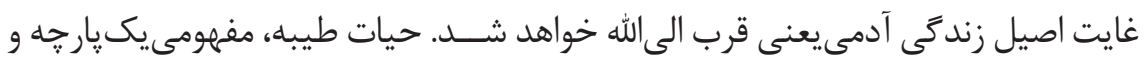
كلى است كه همه ابعاد فردى و اجتماعى زندگى انسان را دربرمى گيرد و شئون گَوناگونى دارد كه در ارتباط و تعامل با همديخر و با محوريت شــأن اعتقادى، عبادى و اخلاقى، آن را محقق مى سازند؛ تأسى به اولياى الهى و تولا و اطاعت از آنها و دشمنى با دشمنان راه خدا و اولياى خداوند، تنها راه تحقق كامل حيات طيبه در مســير قرب الى الله است(مبانى نظرى تحول بنيادين در نظام تربيت رسمى عمومى جمهورى اسلامىايران، • وس ا: 99- • 9). 


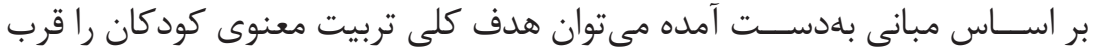

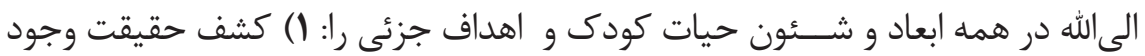

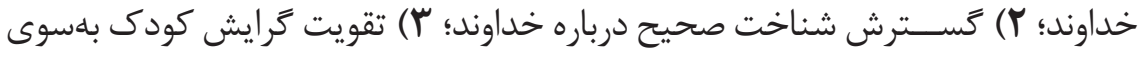

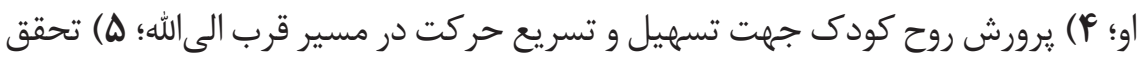

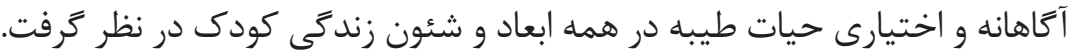

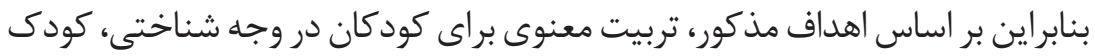

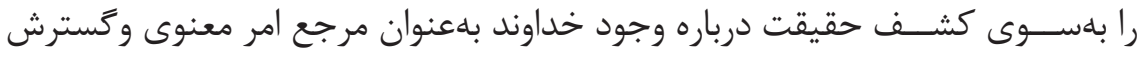

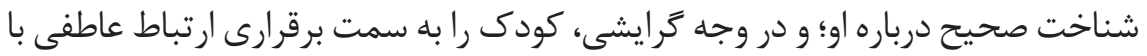
خداوند و گسترش محبت نسبت به او؛ و در وجه عملى نيز كودى را بهسوى ار ارده و عمل در همه ساحتها جهت تحقق حيات طيبه در سطوح متناسب سوق مىدهد.

\section{○ اصول تربيبت معنوى براى كودكان}

در اين بخش به استنتاج سه اصل مهمم از اصول تربيت معنوى براى كودكان در وجه مدان

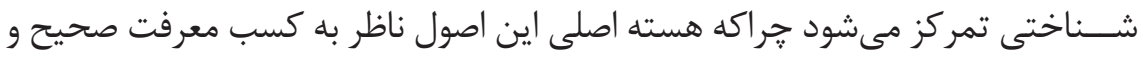

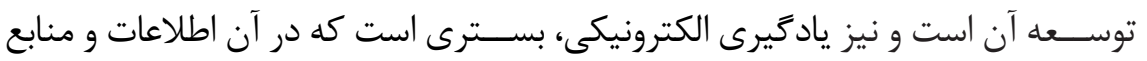

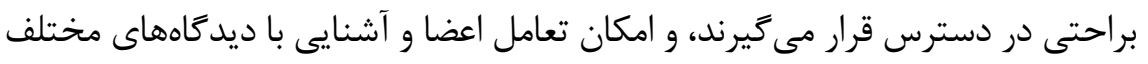

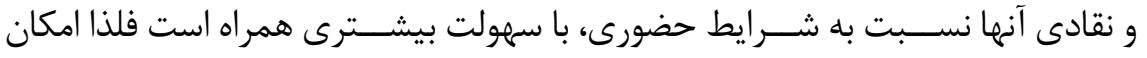
تحقق بيشترى دارند. اين اصول عبارتند از: الف) يرورشانديشه و اعتقادات صحيح درباره

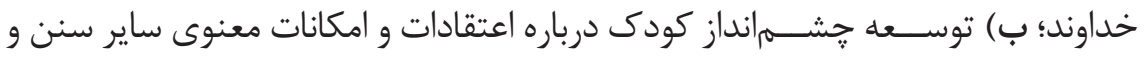
جشم|ندازها؛ و ج) يرورش تفكر انتقادى.

\section{الف) اصل يرورشانديشه و اعتقادات صحيح درباره خداوند:}

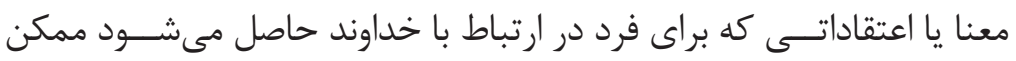

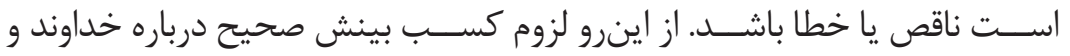

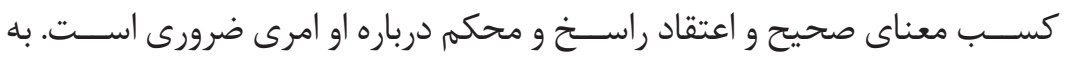

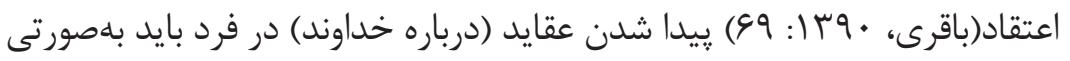

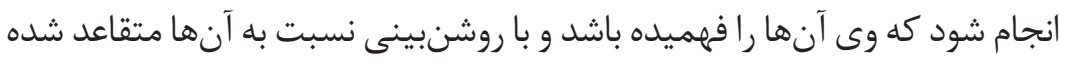

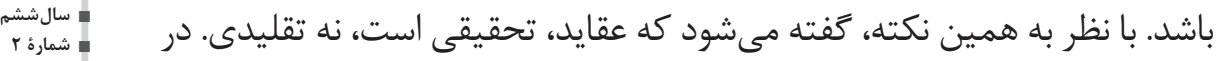

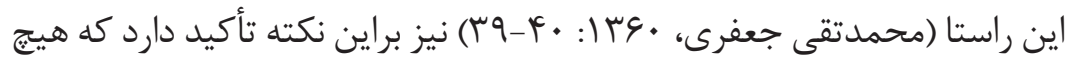


انســانى نمىتواند ادعاى برخوردارى از "حيات معقول "نمايد مكَر اينكه از هويت،

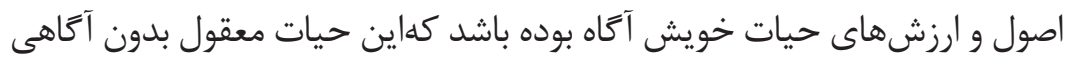

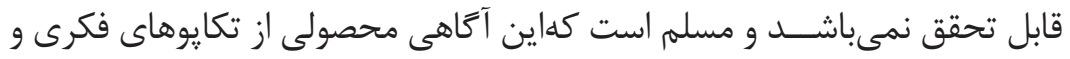

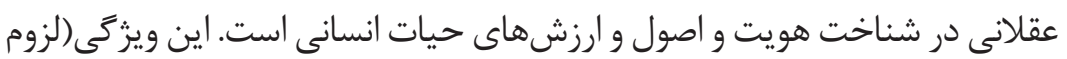

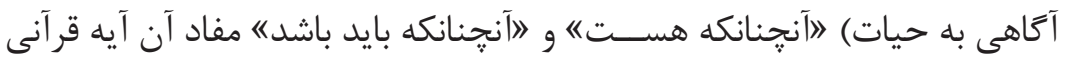

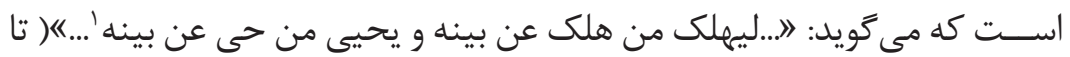

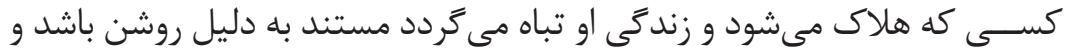

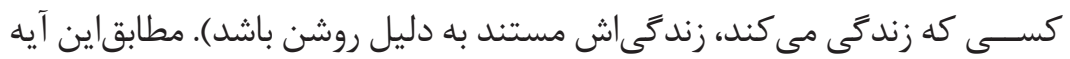

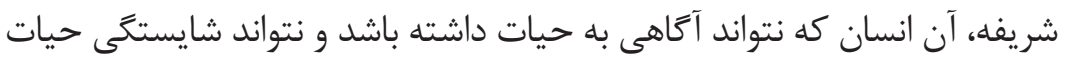

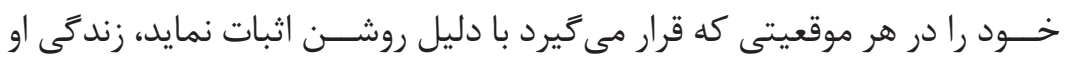
حيات معقول نبوده بلكه يديدهاى نآَّاه و در مجراى قوانين طبيعت و زور كوئىها

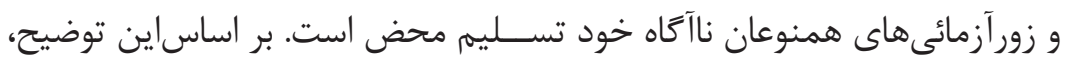

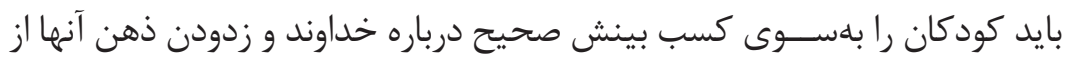
تصورات ناقص و خطا هدايت كرد.

ب) اصل توسعه جشممانداز كودى درباره اعتقادات و امكانات معنوى ساير سنن و جشمماندازها كســب بينش صحيح دربــاره معنا، ارزش و حقيقت غايى در ســاير ســنـن

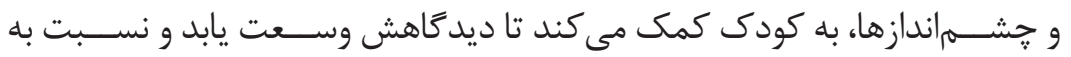
اعتقاداتى كه در اين خصوص اتخاذ مى كند با آكاهى و بصيرت بيشتر اقدام نمايد.

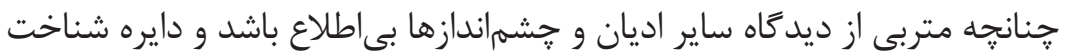

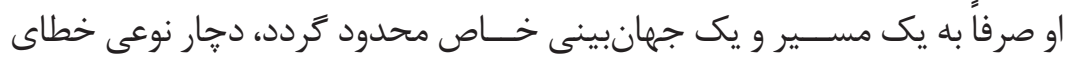

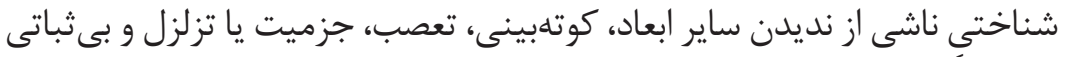

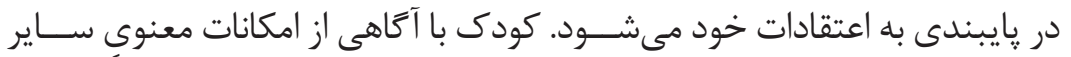
ســن و جشماندازها، قادر به ارزيابى ارزشهاى حيات خود در ميان سنن مختلف

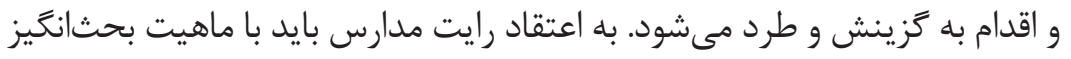

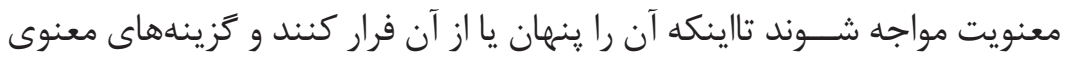


متعدد بايد در قالب طيفى از ادعاهاى مربوط به حقيقت غايى بررســى شوند. وى هشـــار مىدهد كه اخر مواجهه ما با هر يك از ادعاهاى مذكور، فكورانه، آتاهانه و انتقادى نباشد در معرض خطر بنيادگر ايى قرار مى گيريم (35-3right, 2000:34). ايــن اقدام دربردارنده دلالتهايى براى حيات معنوى كودكان اســت زيرا به آنان كمــك مى كند دربــاره جهت گيرى معنوى خود با درايت، بصيرت و حساســيت بيشترى عمل كنند. در مجموع، مىتوان اصل اول و دوم را ذيل اصل كلى يرورش ســـواد معنوى كودكان صورتبندى نمود. با اين توضيح كه، ســـواد معنوى به كــودكان كمك مى كند كه هم درك آنها درباره معنا، هدف، ارزش و حقيقت غايى زندگى از منظر دين خود و نيز ساير اديان، ســنن، و عرفانهاى نوظهور توســـه يابد و هم از اين طريق، زمينه يرورش تفكر نقاد در آنها نسبت به ادعاهاى متنوع درباره معانى، ارزشها و حقايق غايى زندگى فراهم شـــود(با اقتباس از Wright, 2000: 114 ). در اين رابطه، آنجهه مشخص است اينكه سواد معنوى بســيار تحت تأثير سواد طلاعاتى و ارتباطى است. گسترش فناورىهاى اطلاعات

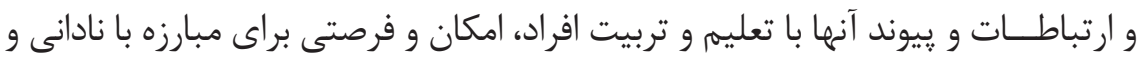
دورى از جهل فراهم ساخته و زمينهى درك واقعيت و ارتقاىانديشه و فكر افراد را ايجاد نموده است.

\section{ج) اصل يرورش تفكر انتقادى}

در عرصه معنويت بهطور خاص، قابليت انديشــهـورزى و تفكر انتقادى بســيار مهرم و حياتى اســت زيرا معنويت، ناخزير در عقايد مربوط به وجودهاى مقدس در جهان درگير مىشود. از اينرو، متربيان بايد از عقايد توهمى و غلط آكاه باشد. اين

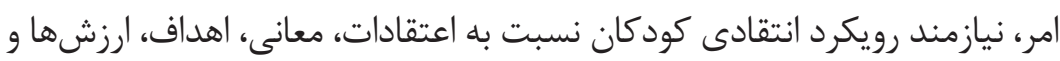
حقايق غايى مطرح شده در فرهنگَشان مىباشد. از منظر رايت نيز معضل تربيت معنوى معاصر، شكست آن در مواجهه انتقادى با ابهام معنويت است و عمدهترين

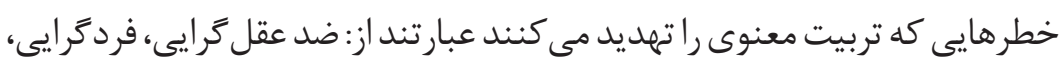
ذهن گرايى، احساس گر ايى. لذا كودكان بايد از قدرت نقد سازنده برخوردار باشند تا بتوانند ســـت معنوى خود را در ميان ديخر فرهنَ ها و سنتهاى معنوى ارزيابى 
در متون اســلامى نيز بر لزوم نغاه انتقادى نســبت به عقايد مورد تأكيد شده است.

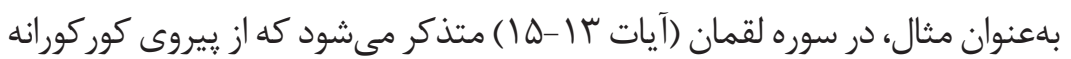
از والدين و يذيرش عقايد مشر كانه آنان برحذر باشيد. بر اساس آيات فوق، معلم بايد

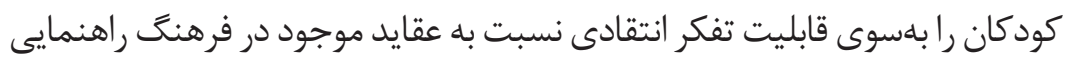
و از تقليد كوركورانه و يذيرش عقايد شركىآلود و نادرست نهى كند.

\section{فر صتهاى يادكيبرى الكترونبكى براى تربيبت معنوى كودكان}

فرصتهاى يادگيرى الكترونيكى براى تربيت معنوى كودكان به منظور تحقق

اصول تربيت معنوى را مىتوان در موارد زير برشمرد:

\section{رشد و افزايش سواد معنوى از طريق منابع باز}

بســتر يادَيرى الكترونيكى با برخوردارى از قابليت بارگزارى منابع بلويزه

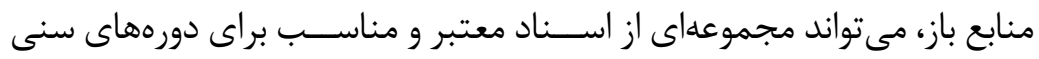
مخاطب را در اختيار قرار دهد كه امكان سفارشى كردناين بسترها متناسب با نياز كودكان در راستاى تحقق اهداف تربيتى نيز امكانيذير است. اين منابع متن باز باويزگَى فرامتنى و فرارسانهاى فرصت بررسى ارزش ها و حقيقت غايى زندگى طبق دين اســلام، اعتقادات و شناخت خداوند بهعنوان مرجع امر معنوى و نيز جستجو در مورد ابهامات و سؤالات در حوزه مسائل معنوى را مىدهد كه شايد در غير از بستر يادگيرى الكترونيكى به اين شكل فراهم نباشد. در همين رابطه برخى محققان (eate Y \& ( Rea, 2020; Jacobus Potgieter, 2015) معتقدند مىتوان بينش و درك معنوى كودكان را از طريق اتصال به منابع مختلف در حوزه مسائل معنوى افزايش داد. آنها همجنين براين باورند كه بستر ياد كيرى الكترونيكى در مقايسه با بسترهاى سنتى كه معلم در آن مهمترين منبع شناخت كودك است، فرصت بيشترى براى رسيدن به شناخت همه جانبه براى كودكان فراهم مى آورد.

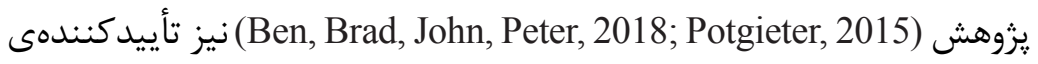
ايسـن فرصت يادگيرى الكترونيكى براى تربيت معنوى كود كان از طريق امكانات

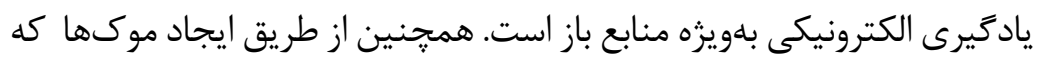
اشاره به دورههاى آموزشى آنلاين دارد، مىتوان فرصتى را براى كودكان فراهم 
كرد تا آنها بتوانند بهطور رايگان از هر نقطهاى در دورههايى كه با اهداف تربيت معنوى تشـــكيل مىشود شركت كنـند. دراين راســـا موكها را مىتوان در دو شيوه براى افزايش ســـواد و بينش معنوى كودكان طراحى نمود؛ در شيوه اول مانند يك مربى، كودك را در مســير مشــخصى هدايت مى كند و در شيوه دوم

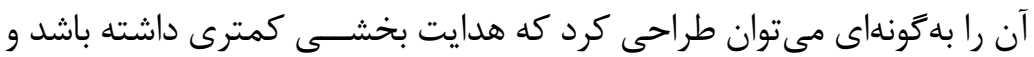
محتواها در اختيار كودكان قرار كيرد تا آنها از طريق جستجو و تعامل براى كسب بينش به تلاش و جستجو واداشته شوند. بهعلاوه، منابع باز در قالبهاى مختلف محتوايــى مانند فيلم، متن، صوت، كليٍ به مربيــان و معلمان تربيتى فرصت مى دهد كه به شــكلى جذاب، مهيج و متناسب با سطح شناختى كودكان، ذهن آنها را درباره مسائل مختلف مربوط به حوزه تربيت معنوى به جالش فراخوانند و محتـــوا را به شــكل مختصر و جذاب به آنها ارائه دهند. بهطور مثال موشــن كَرافى هاى مختلف مى تواند فلســفهى اعمال دينــى را از زاوياى مختلف ارائه و

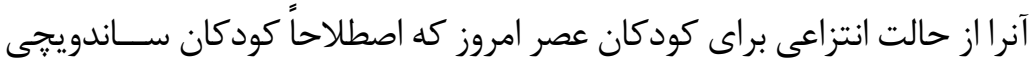
محسوب مىشوند، خارج نمايد.

\section{دسترسى به منابع انسانى مرجع با كمترين محدوديت}

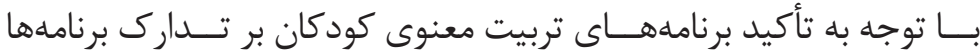
و فرصتهايى جهت ظهور ايمان شــخصى، بلوغ عاطفـى، و صداقت، برخى از ابزارها و برنامههاى موجود در بســتر يادگيرى الكترونيكى، فرصتهاى مناسبى براى كســب دانش، افزايش قدرت شناخت و تحليل، برقرارى روابط اجتماعى و يرورش حس همدلى فراهم مى كنـــد (اعظمى و عطاران، وبا ). بدينترتيب، زمينه براى شــكل گيرى ياد كيرى همدلانه در بســتر يادگيرى الكترونيكى نيز فراهم مىشـــود؛ جرا كه فرصتهاى روابط آنلاين مشترك بهعنوان مؤلفأه مرهم شــكل گيرى تربيت معنوى در بســتر يادگيرى الكترونيكى بيان شـــده است (Association of Theological Schools, 2005: 181) الكترونيكى مى توان با استفاده از نرمافزارهاى ناهمزمان مانند ويكى '، لينكدين'، "ِ 


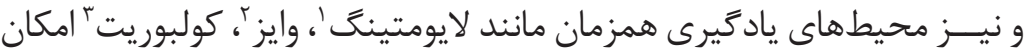
كَتخَو با افراد معتبر و مرجع براى بحث در مورد معانى، اهداف، ارزشها، عقايد، حقيقت غايى را براى كودكان فراهم ســاخت.اين ابزارها به دليل داشتن امكان بـ بـان

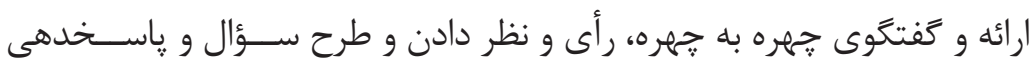
ضمن برقــرارى تعامل مطلوب مىتوانند كَفتخو بـــا كمترين ييامد منفى براى اعضا را فراهم نماينـــد (كرامتى، وجس (1). در اين فضا كودكان در صورت تمايل، با مخفىىســازى هويت خود از طريقاين ابزارهـــاى ارتباطى مى توانند آزادانه به بيان مســـائل و دغدغههاى دينى و معنوى خود بيردازند بدوناينكه مورد توبيخ مستقيه قرار گيرند و از طرفى، به معلمان نيز كمك مى كند تا نوع نگاه كودكان و مسائل و مشكلات آنان را در خصوص مسائل دينى و معنوى بهتر درى نمايد

$$
\text { و براى هدايت و راهبرى آنها نيز تارهانديشى كنند. }
$$

\section{تشكيل اجتماعات معنوى}

با توجه به قابليتهاى متعدد بســـترهاى يادگيرى الكترونيكى براى تشكيل

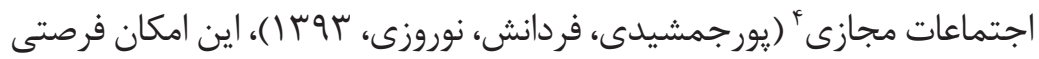
اســت براى اينكه كود كان بتوانند به راحتى با هزينهاندك با همتايان خود از هر منطقــه، با وجود تفاوت در اعتقادات دينــى و مذهبى، بهصورت همدلانه براى كشف حقيقت درباره مرجع امر معنوى و جگَونكى شناخت آن تلاش كنند و به بحث و نقد ديد گاههاى مختلف در خصوص معانى فرهنگَى، ارزشها و حقيقت غايى زندگى بيردازند. همانگونه كه در حال حاضر بســتر يادگيرى الكترونيكى امكان كار كردن افراد دنيا بر روى يروزههاى علوم تجربى را فراهم آورده اســت، مىتوان از قابليتهاىاين بســتر براى يروزههاى معنوى با هدف تحقق اهداف تربيتى اســتفاده نمود. جنين مشـــاركتهاى گروهى مى تواند در درك بهتر و عميق تر مسائل معنوى كودكان راهَشا باشد. فرانسيس بيكن فيسلوف معروف

1.Live Meeting

2. Wized

3. Colaborate

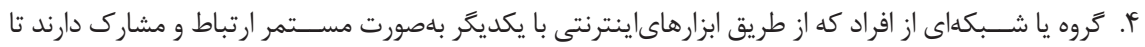

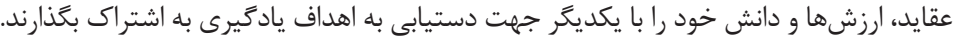




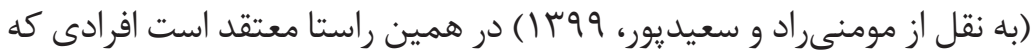
با هم سنخيت دارند و با يكديگر وارد كفتخوهاى معنادار مىشوند، مى توانند به عينى شـــن افكار هم كمك كنند و به فهمى عميقتر در مورد موضوع برسند. به اعتقاد برخى محققان، اجتماعات يادگيرى مجازى فرصت رشد تفكر انتزاعى را براى افراد فراهم مىسازد (Simard, 2021; Gokhale \& Machina, 2018).

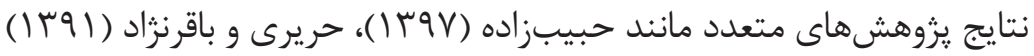
نيز حاكى از ارتباط مثبت بين استفاده از اينترنت و تقويت كاركردهاى شناختى، فراشـــاختى نظير تفكر خلاق و تفكر نقاد است. بر همين اساس جنين بسترى مى توانــد به كود كان جهت دركى ابعاد معنـــوى زند زىى كه ماهيت انتزاعى دارد كمك نمايد.

\section{هالثشهاى يادَّيرى الكترونيكى براى تربيبت معنوى كودكان}

راهبرى و مديريت معلم، و ارزشــيابى دو مورد از جالشهاى مهمم در اين زمينه

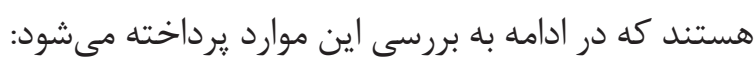

\section{توانمندى مربيان و مديريت فرايند تربيت كودكان}

تربيت معنوى كودكان در بســتر يادكيرى الكترونيكى به معلمان و مربيانى مرى نياز دارد كه علاوه بر تســلط نظرى و تجربــهـ كافى به لحاظ علمى درباره تنوع،

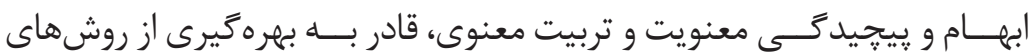
برقرارى تعامل با همه كودكان و تشــويق آنان به مشاركت و كفتخو؛ راهبردهاى ايجاد حس حضور؛ ايجاد جوّ مطمئن و صميمى؛ دادن فرصت عادلانه در تعامل و بازخورد؛ مديريت تعاملات؛ مهارت اســتفاده از ابزارهاى ارتباطى؛ و مهارت در انتخاب اطلاعات و محتواهاى معتبر و مســتند در حوزه مسائل مربوط به ابعاد مختلف تربيت معنوى و كاه توليد محتواى الكترونيكى مناســب باشد كه سطح اين توانمندى در مربيان از خالشهاى يادگيرى الكترونيكى براى تربيت معنوى كودكان است. همجنين، برخوردارى كــودكان از سواد اطلاعاتى كافــى بلمنظور مهارت

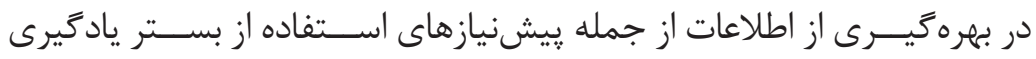


الكترونيكى در فرايند تربيت معنوى آنها اســت. سواد اطلاعاتى وسيلهاى است براى توانمندســازى فردى در مهارت تحليل و اتخـــاذ تصميمات محققانه و يا استقلال در جستجوى حقيقت (ميرحسينى و شعبانى، وq | ). بنابر اين استفاده از بستر يادَيرى الكترونيكى براى توسعه تربيت معنوى كودكان تاحدى در گرو سواد اطلاعاتى و رسانهاى آنها است، براى اينكه بتوانند سره از ناسره و درست از نادرست را تشخيص دهند و بتوانند تحليل و نقد درستى در خصوص موضوعاتى كه منجر به توسعه تربيت معنوى آنها مى شود، داشته باشند.

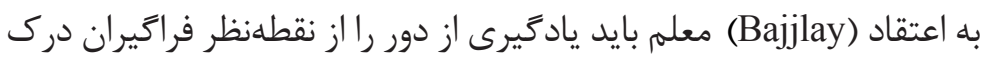
كند(نقل از زمانى و مدنى، • وب ( ). يكى از مهرمرين عوامل در دستيابى به جنين محيطى وجود معلم كاردانى است كه توانايى تفهيهم انتظارات و احترام به سبكها

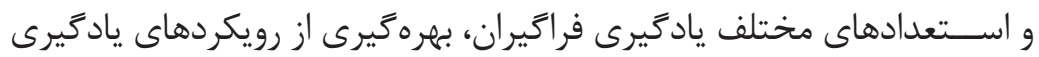
مشاركتى و حل مســأله (زمانى و مدنى، • وس ()، توانمندى شناسايى ايدهها و مفاهيم ارزشمند، ايجاد نظم مفهومى، سازماندهى فعاليتهاى يادَّيرى، هدايت

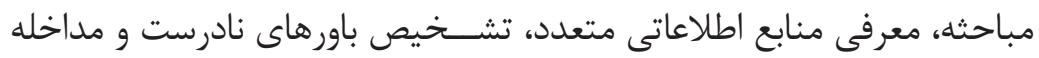
بههنَام را داشته باشـــــ اگر معلمان فرايند تربيت معنوى را با كمك ابزارهاى الكترونيكى و راهبردهاى مناســب نتوانــــد باهوبى هدايت كنـند بدينمعنا كه قادر به استفاده از ابزارها براى انواع بازخوردهاى تأملى، توضيحى و انخيزشى به كودكان و راهبردهاى فعال ســازى يادگيرنده (كه در حوزه تربيت معنوى حائز اهميت اســت)؛ نباشند، نه تنـها كود كان به هدف موردنظر دست نمىيابند بلكه دجار بىعلاقكَى نسبت به موضوع مىشوند. در اين صورت، نهاد تربيت، فرصت لازم را براى كمك به كودى جهت اتخاذ جهت گيرى معنوى فكورانه، حساس و فعال نسبت به اهداف، ارزش ها و حقيقت غايى زندگى و جگَونكى ارتباط با آنها

$$
\text { راز المست مىدهد. }
$$

يادكيرى و مشـــاركت فعال فراخيران هنغام يرداختن به مسائل معنوى در بستر ياد گيرى الكترونيكى نيازمند نظارت و راهبرى مربيان توانمندى است كه به فراگيران كمك كند تا به واسطه تعيين اهداف مشترك، تحقيق و جستجوى مشترك، تلاش براى يادَيرى و تصميمزيرى مشاركتى به سطوح عميقترى از 
دانش و آكاهى دســت يابند. در جنين محيطى، صلاحيت داشتن معلم ناظر به

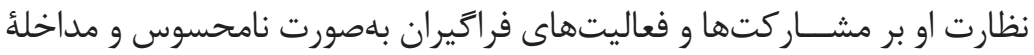

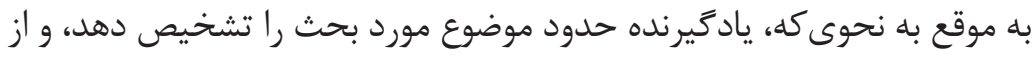
ايجاد بحثهاى نامرتبط، يراكنده و غيردقيق جلو گيرى شود از جمله جالشهاى

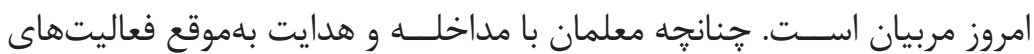

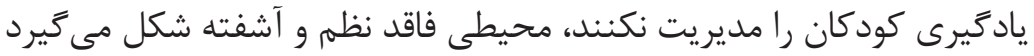

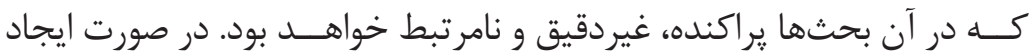
جنين فضا و شرايطى در بستر فضاى مجازى ياددهى ـ يادَّيرى، فرايند تربيت فرايند تربيت معنوى كودكان عقيم مى ماند.

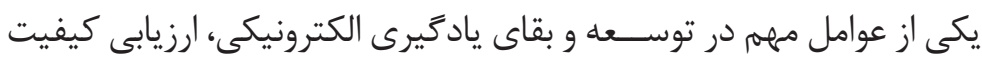
برنامه آموزشى از طريق ارتقاى كيفى راهبردهاى نظارت و ارزشيابى برنامه است.

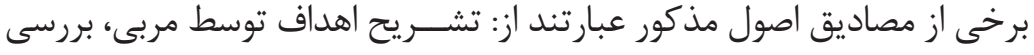

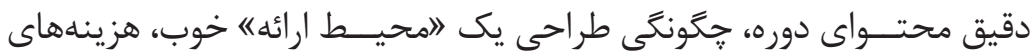
دسترسى، بررسـى ميزان تعاملى كه دوره ارائه مى كند، بررسى و و تعيين ميزان

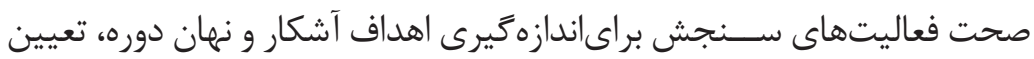

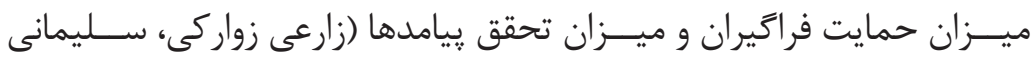

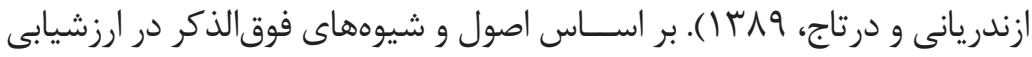
فراگيران در بستر يادگيرى الكترونيكى، مربيان در فرايند تربيت معنوى كودكان

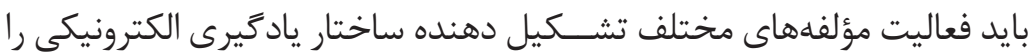
به نحوى منســـم مورد توجه قرار دهند و بهَّونهاى اقدام نمايند كه آنان را در

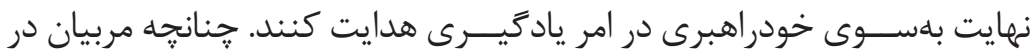

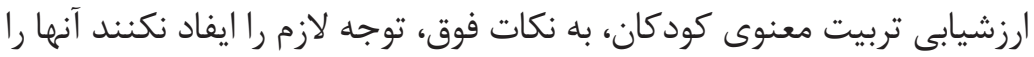
يا بلسوى سطحىنكرى و يادكيرىهاى سطحى و مشار كتاندى سوق مى دهند

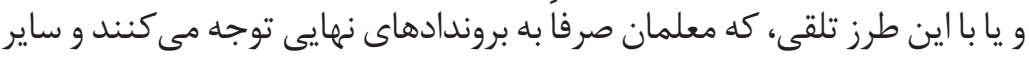

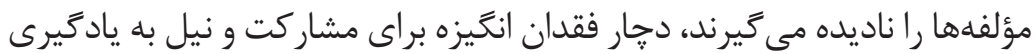


هدف اين تحقيق، تببين مفهوم و اصول تربيت معنوى براى كود كان با تأكيد بر مبانى

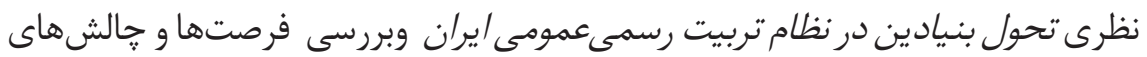
ياد

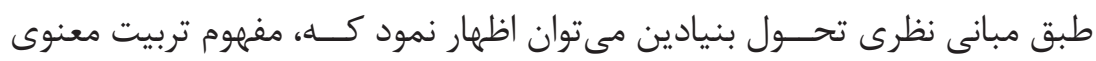

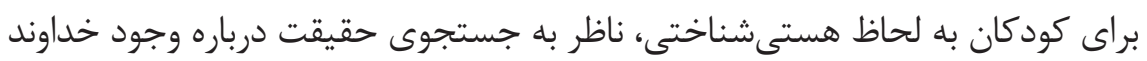

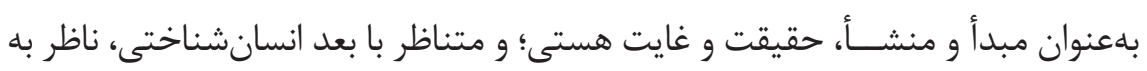

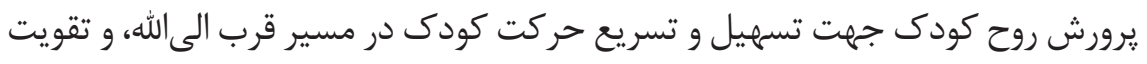

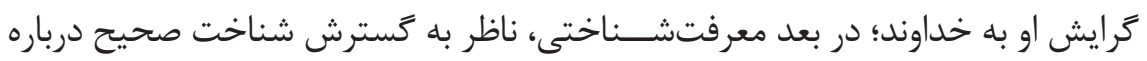

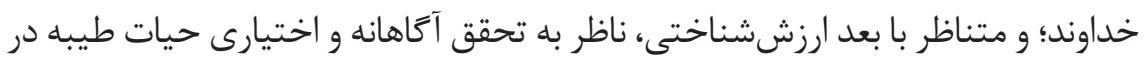

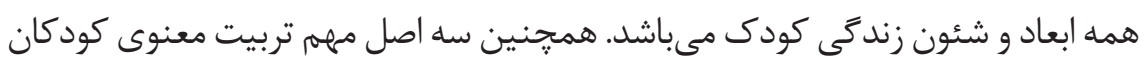

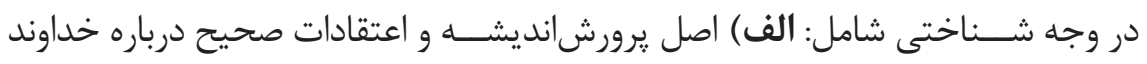

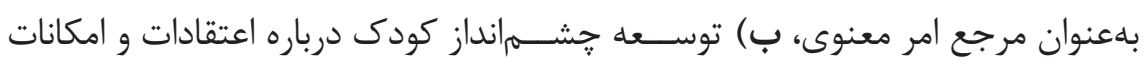

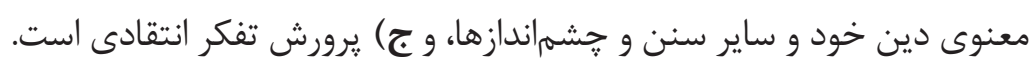

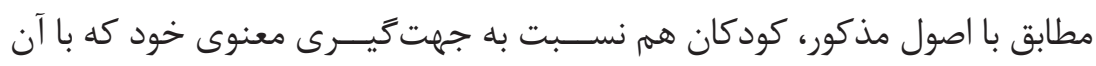

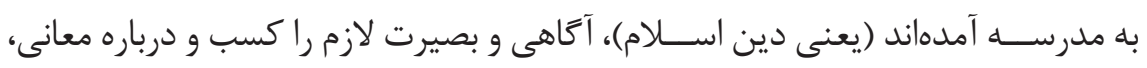

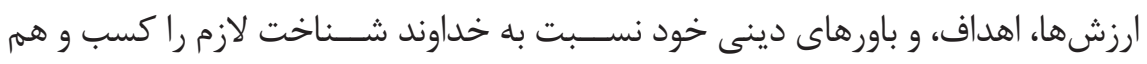

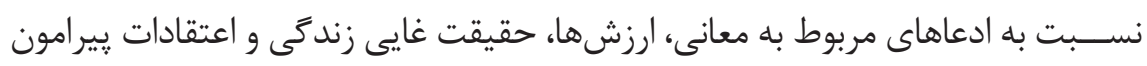

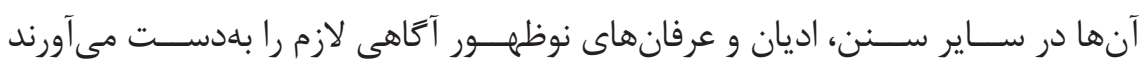

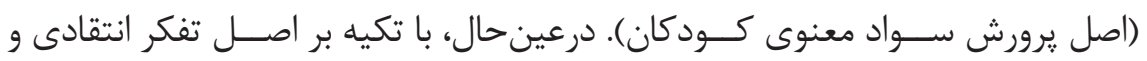

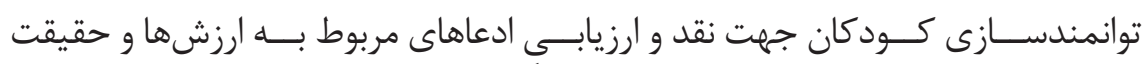

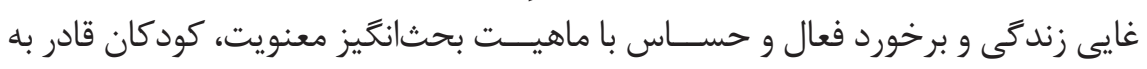

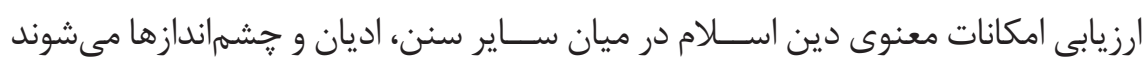

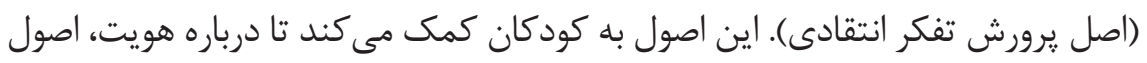

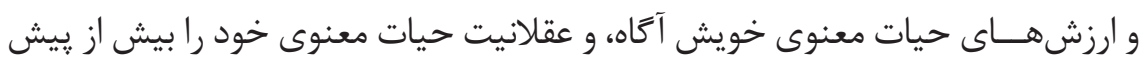

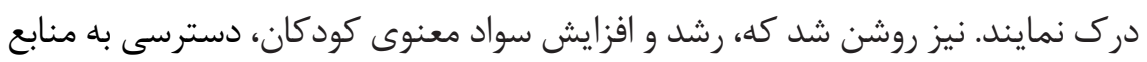

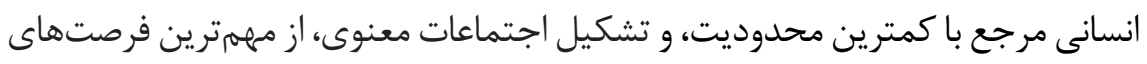


يادگيرى الكترونيكى بـــراى تربيت معنوى كود كان؛ و توانمندى معلم و مديريت فرايند

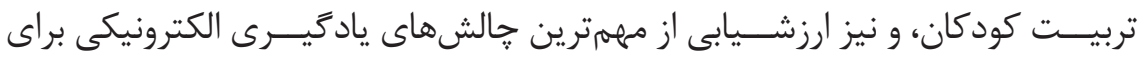
يادكيرى معنوى بهشمار مىروند.

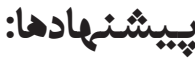

- شناسايى و معرفى منابع متن باز در حوزهُ تربيت معنوى از طريق دروس مرتبط - تهيه و توليد محتواهاى الكترونيكى در حوزه تربيت معنوى و انتشار آن با استفاده از ابزارهاى ارتباطى در يلتفورمهاى الكترونيكى. - تحقيق درباره اصول و روشــهاى تربيت معنوى كودكان در ســهـ وجه شـــاختى، گر ايشى و عمل با تأكيد بر مبانى نظرى تحول بنيادين.

- تحقيق درباره جُگَنَى تدارك شرايط لازم براى ارزشيابى وجوه گرايشى و عملى تربيت معنوى كود كان در بستر يادگيرى الكترونيكى.

\section{تُشَّر و قدردانى}

از تمام صاحبنظران و يزوهشگرانى كه ديدكاهها و نتايج يزوهش وهاى آنها 


\section{منابع}

قرآن كريم، ترجمه محى الدين مهدى الهى قمشهاى.

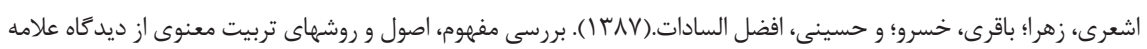

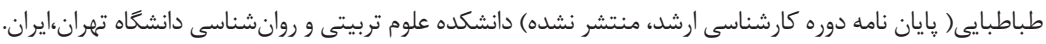

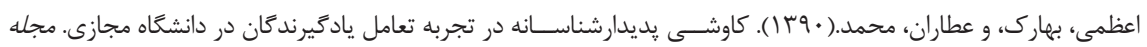

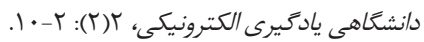

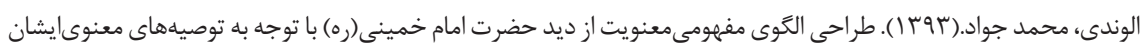

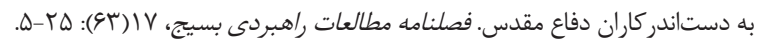

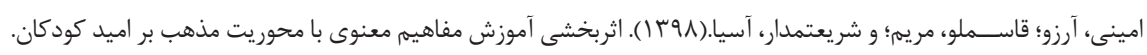

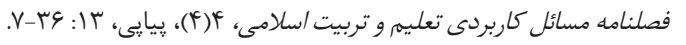

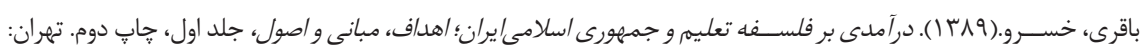

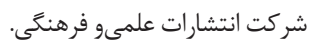

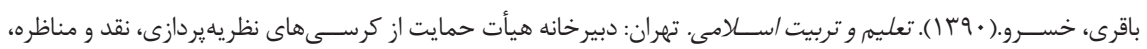
1-rar

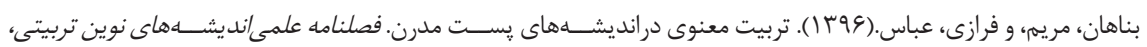

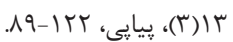

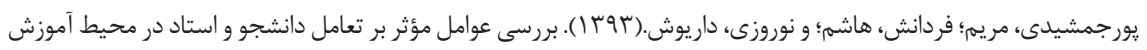

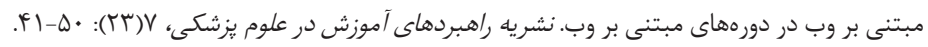

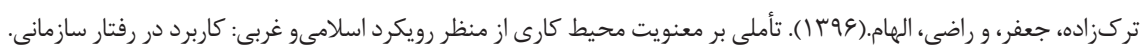

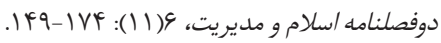

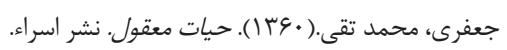

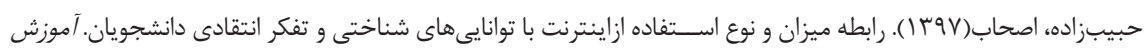

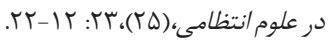

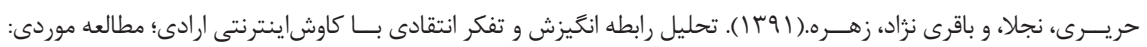

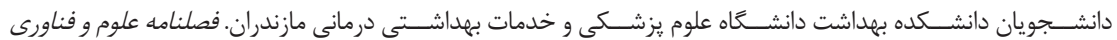

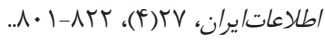

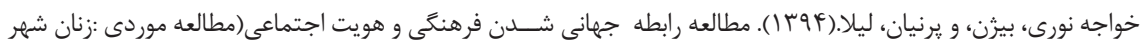

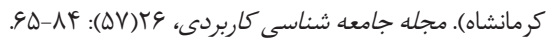

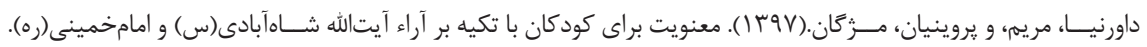

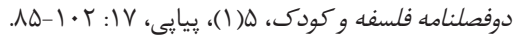

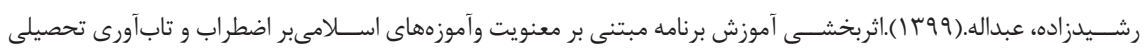

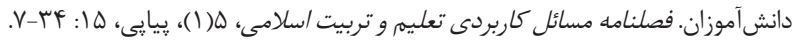

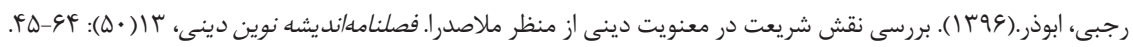

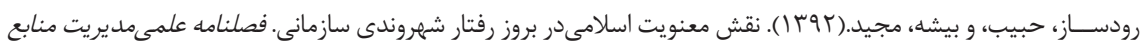

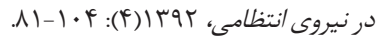

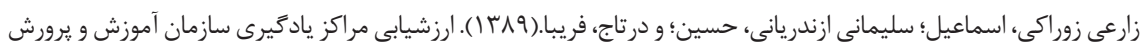

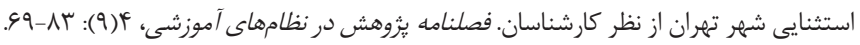

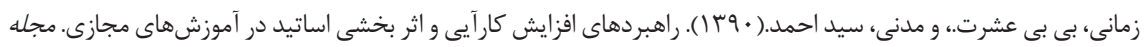

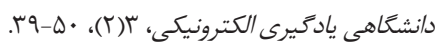

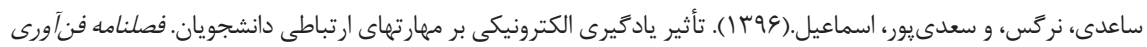

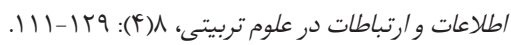




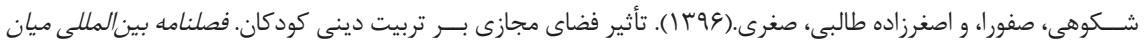

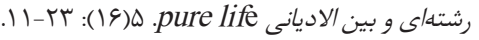

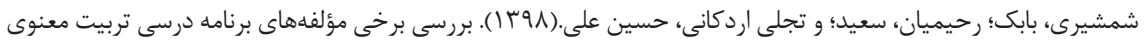

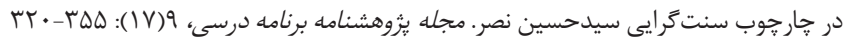

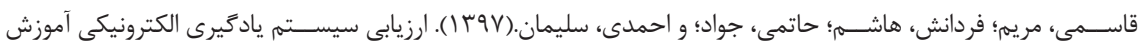

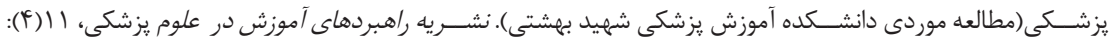

$$
\begin{aligned}
& . F \cdot-\Delta T
\end{aligned}
$$

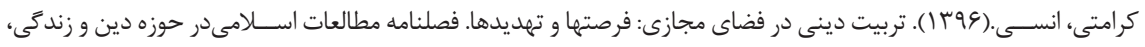$$
. \Delta \Lambda-r \mu \text { r (IV) }
$$

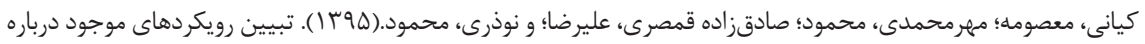

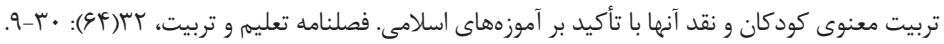

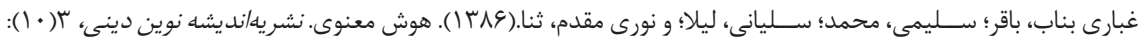$$
.1 r \Delta-1 F V
$$

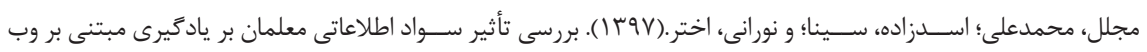

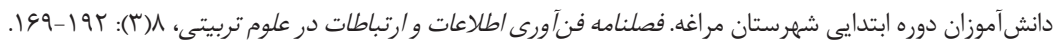

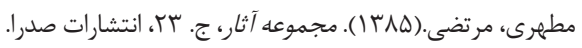

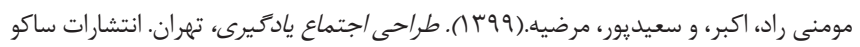

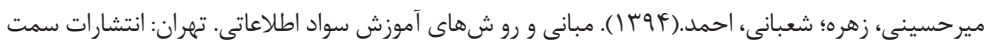

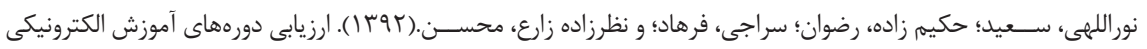

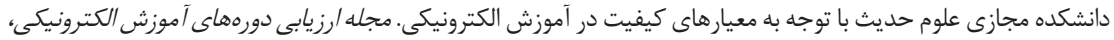

$$
.1-14:(T){ }^{4}
$$

\section{REFERENCES}

Association of Theological Schools.(2005). General institutional standards. Retrieved April 27, 2009, from http://www.ats.edu/ accrediting/standards/05GeneralStandards.pdf

Bagheri Noparast., Kh.(2013). Physical and spiritual education within the framework of pure life. International Journal of Children's Spirituality, 18(1), 46-61.

Ben, F., Brad., W., III,. John.H, \& Peter.J, R.(2018). Describing Spiritual Growth in an Online Religious Education Course. Journal of Research on Christian Education, 27(1): 56-75.

Crawford, M. Rossiter, G.(2006). Reasons for living: education and young people's search for meaning, identity, and spirituality; a handbook. Victoria: Camber well, ACER Press.

Gerasimova, V.G.; Melamud, M.R.; Tutaeva, D.R.; Romanova, Y.D.; Zhenova, N.A.2018)). The Adoption of E-Learning Technology at the Faculty of Distance Learning of Plekhanov Russian University of Economics. Journal of Social Studies Education Research. 9(2), 172-188.

Gellel, A. M.(2014). An Emerging Approach to Spiritual Development Through Religious Education in Maltese Schools. In J. Watson \& et al(Eds.), Global perspectives on spirituality and education, pp. 58-71. Routledge.

Gokhale, A., Machina, K.2018)). Guided Online Group Discussion Enhances Student Critical Thinking Skills. nternational Journal on E-Learning, 17(2). 157-173

Hasanshahi,M., \& Amidi Mazaheri., M.(2016). The Effects of Education on Spirituality through Virtual Social Media on the Spiritual Well-Being of the Public Health Students of Isfahan University of Medical Sciences. J Community Based Nurs Midwifery. 4(2): 168-175. 
Hockridge, D.(2011). What's the Problem? Spiritual Formation in Distance and Online Theological Education. International Journal of Christianity \& Education. 54(1): 25-38.

Hoffman, S.(2010). Teaching the humanities online, Routledge, New York.

Jacobus Potgieter, F.(2015). Towards a Sprituality of Open Distance Learning. Journal for Open and Distance Learning Practice. 37(2):64-78. DOI:10.25159/0256-8853/58

Lowe, S.D., \& Lowe, M.E.(2006). Spiritual Formation in Theological Distance Education: An Ecosystems Model. Spiritual Formation in Theological Distance Education: An Ecosystems Model. Christian Education Journal. Series 3, 7(1): 85-102.

Moberg, D. O.(2010). Spirituality research: measuring the immeasurable? Perspective on science and christian faith. Journal of Religious Education, 62(2): 99-114.

Negahban MB, Selvaraja A.(2019). The Application of Interactive and Intelligent Web in E-Learning. Interdisciplinary Journal of Virtual Learning in Medical Sciences. 10(4): 74-77.

Ramsey, A. E.(2006). Poor in spirit? The childs world, the curriculum and spirituality. In A. Thatcher(Ed.), spirituality and education, 111- 123. Springer.

Rea, A., \& Yeates, N.(2020). Open Sourcing the Pedagogy to Activate the Learning Process. International Journal of Information and Communication Technology Education. 16(2): 1- 17.

Simard, D.A. Facilitation strategies and the acquisition of higher order thinking skills in online learning communities: A study of theory development. Ph.D. thesis, Capella University. Retrieved May 15, 2021 from https://www.learntechlib.org/p/129510/

Watson, J.(2009). Responding to difference: Spiritual development and the search for truth. In M. De Souza \& et al.(Eds.), International handbook of education for spirituality, care and wellbeing(pp. 821-839). Springer.

Wright, A.(2000). Spirituality \& education. London: Rutledge.

Watson, J., De Souza, M \& Trousdale, A.(2014). Global perspectives and contexts for spirituality in education. In J. Watson \& et al.(Eds.), Global perspectives on spirituality and education(pp. 294-315). Rutledge. 